\title{
P- $\Delta$ Effects on the Reliability of Oil Offshore Jacket Platforms in Mexico
}

\section{Efectos P- $\Delta$ en la confiabilidad de plataformas petroleras costa fuera tipo jacket en México}

\author{
De León-Escobedo D. \\ Universidad Autónoma del Estado de México \\ Ciudad Universitaria, Toluca, Estado de México \\ Correo:daviddeleonescobedo@yahoo.com.mx
}

\author{
Campos D. \\ Instituto Mexicano del Petróleo, México \\ Correo:dcampos@imp.mx
}

Información del artículo: recibido: agosto de 2008, reevaluado: mayo de 2010, aceptado: septiembre de 2011

\begin{abstract}
Given the important economic consequences of an oil platform failure, all the aspects of its structural behavior and safety issues need to be carefully considered. In particular, P- $\Delta$ effects on the deck legs of marine offshore jacket platforms may be relevant when the deck height and the vertical load are significant. In this paper, the impact of the moment amplification, due to slenderness of the deck legs, on the platform safety is examined and appraised from the viewpoint of the structural reliability. The formulation is applied to a typical tall deck marine platform under the environmental loading at the Bay of Campeche, Mexico, and its reliability index is calculated with and without the P- $\Delta$ effect. The results presented herein may be used to improve the current practice in the design and assessment of offshore marine platforms in Mexico and to update the current version of the code.
\end{abstract}

\section{Resumen}

Dadas las importantes consecuencias económicas de la falla de una plataforma petrolera, todos los aspectos de su comportamiento estructural y aspectos de seguridad necesitan considerarse cuidadosamente. En particular, los efectos $P-\Delta$ en las piernas de la cubierta de plataformas marinas costa fuera petroleras tipo jacket, pueden ser relevantes cuando la altura de la cubierta y la intensidad de cargas verticales son significativas. En este artículo se examina el impacto que sobre la seguridad de la plataforma tiene la amplificación de momentos, debido a la esbeltez de las piernas de la cubierta, y se evalúa este impacto desde el punto de vista de confiabilidad estructural. La formulación se aplica a una plataforma marina típica, con cubierta alta, bajo la carga ambiental de la Bahía de Campeche, México y se calcula su indice de confiabilidad con y sin el efecto $P-\Delta$. Los resultados presentados aquí pueden usarse para mejorar las prácticas actuales de diseño y evaluación de plataformas marinas costa fuera en México y para actualizar la versión actual de la Norma.

\section{Keywords}

- P- $\Delta$ effects

- structural reliability

- offshore platforms

- deck and global reliability

\section{Descriptores}

- efectos P- $\Delta$

- confiabilidad estructural

- plataformas costa fuera

- confiabilidades de cubierta y global 


\section{Introduction}

Design and assessment of steel structures for offshore jacket platforms in the Bay of Campeche, Mexico, have been under considerable improvement since the 60's. After the Roxanne hurricane, the IMP (Instituto Mexicano del Petróleo) and PEMEX (Petróleos Mexicanos) started extensive studies to develop risk based design and requalification criteria for those structures. A result of such efforts came out in 1997 in the form of the first edition of the Transitory Criteria for Design and Requalification of Offshore Platforms (IMP, 1997), which became later on, the PEMEX Reference Norm (PEMEX, 2000). These codes include target reliability values for design and assessment of these platforms.

However, in order to have a more detailed and reliable estimation of the platform safety, for a proper risk management, it is necessary to explore if the P- $\Delta$ effects are significant over the reliability of typical jacket platforms (De León and Campos, 1999).

Recently, PEMEX has increased operations of exploration and exploitation of oil and gas in the Bay of Campeche. Some of their associated tasks have been the addition of equipment over existing platforms and the installation of new jackets with slender decks on slightly deeper waters. Consequently, there is a reasonable concern about offshore platforms operating with heavy vertical load, and with slender deck legs, as the P- $\Delta$ effect of the deck may have a significant influence on the safety level of the platform (De León, 1999 and 2001). Also, it is not unrealistic for the deck legs to have a high slenderness ratio because of the common requirement for the deck elevation to be high in order to exceed the wave height that may occur during severe storms at sites with larger water depth (API, 1993).

It is well known that the axial behavior of slender elements may be determined by either global or local buckling modes (Bruneau et al., 1998). For this purpose, the deck legs of typical offshore jacket platforms in the Bay of Campeche, Mexico, are analyzed and their global and local buckling capacities compared to identify the instability mode that governs their axial capacities.

Because the wave loading and the capacity are uncertain variables (Ang and Tang, 2007), structural reliability techniques are used to explicitly include the uncertainties underlying the safety assessment process (De León and Ang, 2003).

The structural safety of marine platforms under lateral loads is approximately assessed (Mortazavi and Bea, 1996) by assuming that the platform is a series system composed by: the deck (superstructure), two or more bays (jacket) and the piles (foundation). By con- sidering that, the deck reliability is estimated and incorporated into the global reliability calculations.

The influence of the uncertainty of the vertical load over the deck lateral capacity is also explored as it represents an increment on the overall uncertainty on the platform safety. This uncertainty is mainly due to changes that sometimes are made on the field by the platform manager, before analysis, on the number and weight of equipment located on the platform deck and may this uncertainty have an important effect on the variance of the deck capacity, and latter, on the platform failure probability.

A second moments reliability format (Cornell, 1969; Ang and Tang, 1984) is followed in order to calculate the mean and coefficient of variation of the final moments at the deck legs, after amplification due to slenderness effects. These statistics are used to assess the platform reliability for both conditions: without and with P- $\Delta$ effects.

The results presented herein may be used in future studies intended to contribute to set practical limits on the deck legs slenderness for the Design of new platforms in the Bay of Campeche and, in a longer term, to further extend and upgrade the current version of the reference norm.

\section{Amplification due to slender deck legs}

\section{Structural model}

Usually the deck is considered as a rigid diaphragm that distributes the vertical load uniformly over the deck legs. The primary moments on the deck legs are amplified according to its critical compression buckling load, $P_{c r}$, and the total vertical load $Q$. From the conventional design of steel structures (Chen, 1997; Galambos et al., 1996; Gupta and Krawinkler, 2000; Salmon and Johnson, 1996), the amplification factor for each one of the $n$ deck legs, assuming that the total vertical load is equally distributed on the deck legs, is:

$B_{1}=C_{m} /\left[1-Q /\left(n P_{c r}\right)\right]$

Where $C_{m}$ is a constant to consider the type of supports and loading in the member, which may be taken as 1 for the legs platform. See Figure 1 for a simple deck model. The geometry of the deck legs is described in Figure 2.

In order to calculate the amplification factor, the critical buckling load of the deck legs is required. However, for the typical tubular cross sections of the platform legs, the buckling load may be governed by either the global or local instability modes. For that purpose, 
in the section the global and local bucking strengths are obtained and compared.

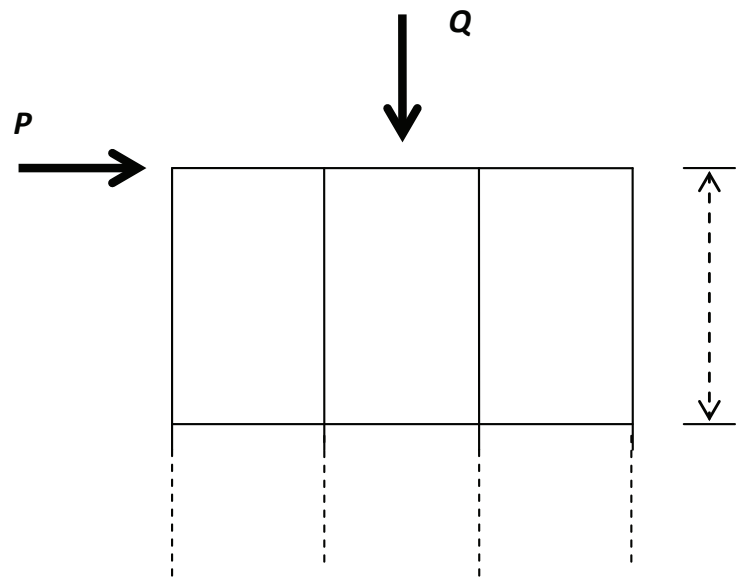

Figure 1. Structural model of the platform deck
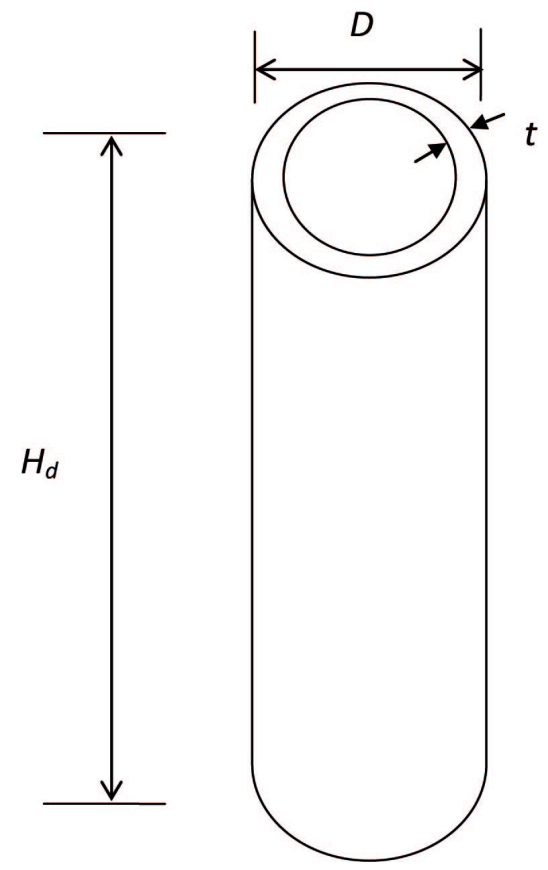

Figure 2. Geometry of deck legs

Lateral loads coming from ocean waves are recognized but, given the large lateral stiffness of this type of structures, and the significant slenderness produced by decks located at high elevations, in this paper $B_{1}$ is the only factor considered to generate amplification, that is, second order effects on the offshore platform. Besides, the purpose of this paper is to assess the amplification due to slenderness of the deck legs and the increment on uncertainty due to P- $\Delta$ effect.

\section{Critical axial buckling load on the deck legs}

From regression analysis of typical platform legs, empirical expressions and their statistics have been proposed for $P_{c r}^{G}$, the global and $P_{c r}^{L}$, the local buckling, (Cox, 1987):

$$
\begin{aligned}
& P_{c r}^{G}=P_{y}\left[1.03-0.24\left(k H_{d} / r\right)^{2} f_{y} / E\right] \\
& P_{c r}^{L}=P_{y}\left[1.79-0.25(D / t)^{0.25}\right]
\end{aligned}
$$

where:

$$
\begin{aligned}
k H_{d} / r & =\text { slenderness ratio } \\
M_{p} & =Z f_{y} \\
P_{y} & =A f_{y} \\
f_{y} & =\text { steel yielding stress of tubular leg cross section } \\
D & =\text { leg diameter } \\
t & =\text { leg thickness } \\
Z & =\text { plastic modulus of tubular leg cross section } \\
A & =\text { cross section area, and } \\
\mathrm{E} & =\text { steel elastic modulus }
\end{aligned}
$$

The coefficient of variation for $P_{c r}$ is 0.1 (Cox, 1987) and for $f_{y}$ is also 0.1 (SPC, 1994). These values are considered typical in the industry because the critical buckling load depends on geometrical parameters which usually have low variability having a maximum of $10 \%$. Also, steel manufacturers have quality assurance process to warranty a low variability on the yielding stress on the order of $10 \%$.

\section{Statistics of the final moments after amplification}

Due to the uncertainty on the wave loading, the primary ultimate moments obtained at the deck legs ends, $M_{u}$, are considered as random variables. Given the amplification factor depends on the vertical load and the critical buckling load on the deck legs, and that they are also uncertain, the final moment after amplification will be also uncertain.

As before was said, due to its simplicity, a first order second moments reliability format is followed to develop the analytical expressions for the statistics of the deck legs final moments after amplification. The usual notation of an upper bar for mean value, $\sigma$ for standard deviation and $C V$ for coefficient of variation is followed.

$$
\begin{array}{ll}
M_{f 1}=M_{u} & \text { without P- } \Delta \\
M_{f 2}=M_{u} B_{1} & \text { with P- } \Delta
\end{array}
$$




$$
\begin{aligned}
& E\left[M_{f 2}\right]=\bar{M}_{u} /\left[1-\bar{Q} /\left(n \bar{P}_{c r}\right)\right] \\
& \sigma_{M_{f 2}}=\left[1 /\left[1-\bar{Q} /\left(n \bar{C}_{c r}\right)\right]^{2} \sigma_{M_{u}}{ }^{2}\right. \\
& {\left[\left(-\bar{M}_{u}\right)\left(-1 / n / \bar{P}_{c r}\right) /\left(1-\bar{Q} / n / \bar{P}_{c r}\right)^{2}\right]^{2} \sigma_{Q}{ }_{Q}+} \\
& {\left[-\bar{M}_{u}\left(\bar{Q} / n / \bar{P}_{c r}{ }^{2}\right) /\left(1-\bar{Q} / n / \bar{P}_{c r}\right)^{2}\right]^{2}{\sigma_{P_{c r}}}^{2}} \\
& C V_{M_{f 2}}{ }^{2}=C V_{M_{u}}{ }^{2}+\bar{B}_{1}{ }^{2} \sigma_{Q}{ }^{2} /\left(n \bar{P}_{c r}\right)^{2}+\bar{B}_{1}{ }^{2} \bar{Q}^{2} /\left(n \bar{P}_{c r}{ }^{2}\right)^{2}{\sigma_{P_{c r}}}^{2} \\
& C V_{M_{f 2}}{ }^{2}=C V_{M_{u}}{ }^{2}+\left[\bar{B}_{1} /\left(n \bar{P}_{c r}\right)\right]^{2} \sigma_{Q}{ }^{2}+\left[\bar{B}_{1} \bar{Q} /\left(n \bar{P}_{c r}\right)\right]^{2}{\sigma_{P_{c r}}}^{2} \\
& C V_{M_{f 2}}=C V_{M_{u}}{ }^{2}+\left[\bar{B}_{1} \bar{Q} /\left(n \bar{P}_{c r}\right)\right]^{2}\left[C V_{Q}{ }^{2}+C V_{P_{c r}}{ }^{2}\right]
\end{aligned}
$$

Therefore, the amplification of the coefficient of variation of the moment due to P- $\Delta$ effects $\left(F A C V_{M f 2}\right)$, is:

$$
F A C V_{M_{f 2}}=\sqrt{1+\left[\bar{B}_{1} \bar{Q} /\left(n \bar{P}_{c r}\right)\right]^{2}\left[\left(C V_{Q}{ }^{2}+C V_{P_{c r}}{ }^{2}\right) / C V_{M_{u}}{ }^{2}\right]}
$$
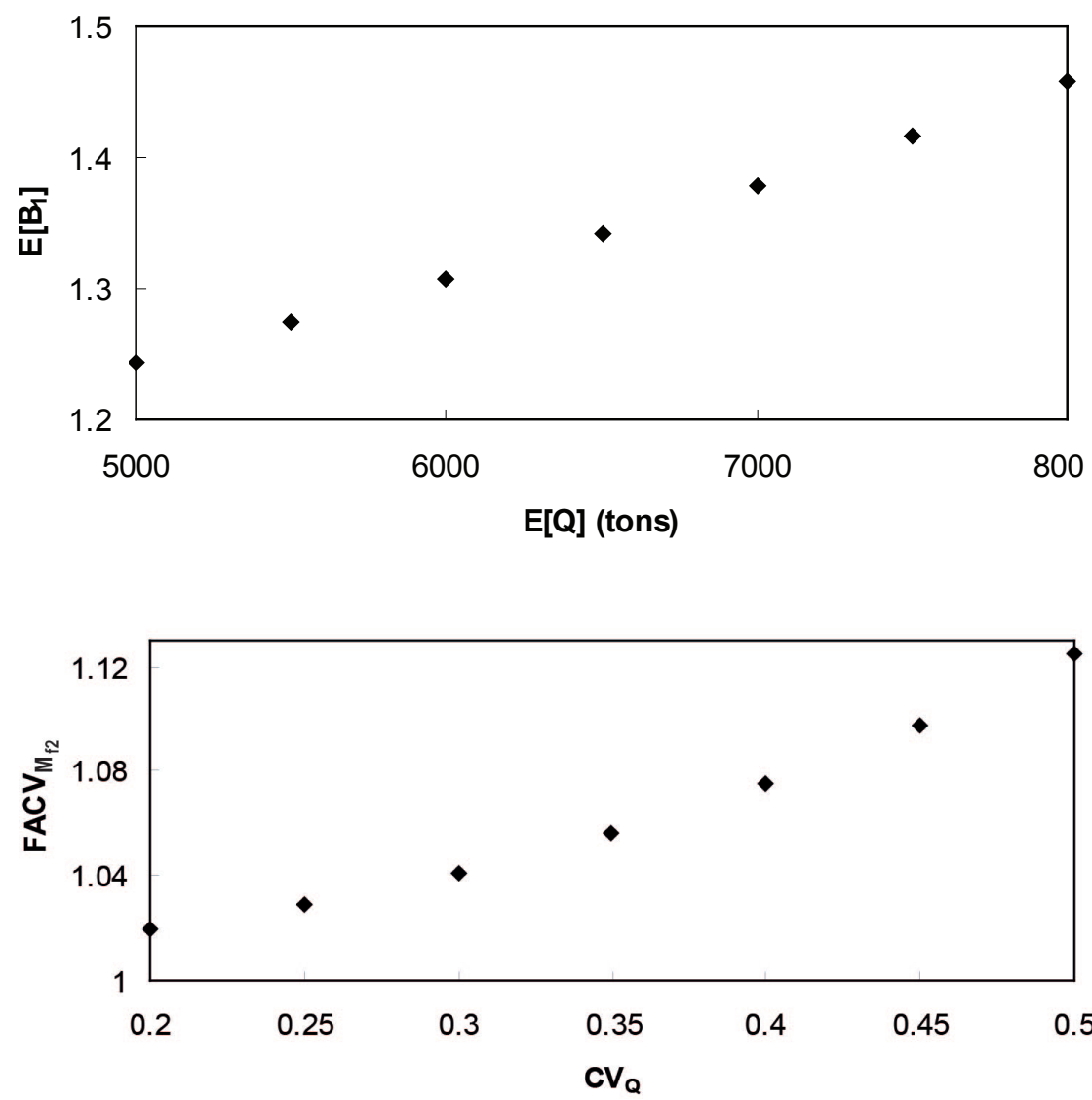

The expected amplification factor in terms of the mean vertical load is shown in Figure 3 whereas the amplification factor of the coefficient of variation of the final moment appears, as a function of the uncertainty on the vertical load, in Figure 4.

\section{Deck reliability}

The calculation of the deck reliability index is performed by assuming that the load and resistance are lognormal variables:

$$
\beta=\left(\lambda_{R}-\lambda_{W}\right) / \sqrt{\zeta_{R}^{2}+\zeta_{W}^{2}}
$$

where:

$$
\lambda=\ln \mu-1 / 2 \zeta^{2}
$$

for the capacity $R$ and the load $L$, and:

$$
\zeta=\sqrt{\ln \left(1+C V^{2}\right)}
$$

Figure 3. Expected moments amplification factor at the deck legs of a typical tall deck platform for several mean vertical loads
Figure 4. Amplification factor of the CV of the final moments at the deck legs as a function of the $\mathrm{CV}$ of the vertical load 


\section{Platform global reliability}

The platform global reliability index is obtained from its global failure probability, which is determined in terms of the components failure probabilities.

The components reliability indices are calculated, in a simplified way, through commercial software (Stear et al., 1997) which considers the generation of mechanisms through plastic hinges and the bracings instability as the most probable failure modes. The limit state normally considered is the event where the lateral force produced by the environmental loading exceeds the platform base shear resistance.

The platform failure probability is calculated by assuming that the environmental loading and the resistance are lognormal random variables and the platform failure probability is calculated from the above mentioned model of a series system.

The piles, jacket substructure and deck are considered as components and their lateral strength and loading are considered as the capacity and demand of each component. Statistics of the capacity and demand are calculated in terms of the statistics of input parameters, as the environmental wave, wind and current typical for the platform site.

Wave-on deck loading is considered as the critical loading condition and the deck lateral capacity is obtained by including the $\mathrm{P}-\Delta$ effect.

For the platforms studied in this paper, the deck structural reliability is calculated through the limit state related to the P- $\Delta$ effect, the final bending moments at the legs ends. In case the deck reliability is below the one for the shear failure mode, it would mean that the bending with P- $\Delta$ effect is a more probable failure mode that the shear one. In that case, the deck reliability on shear is substituted by the reliability on bending with $\mathrm{P}-\Delta$ effects.

The failure probability of each component is calculated by using the FORM approximation (Ang and Tang, 1984) and the statistics of the involved parameters. The components failure probabilities are combined to generate the lower and upper bound of the global failure probability (Ditlevsen, 1979). The global reliability is estimated from the assumption that the global probability of failure is the geometrical mean between the bounds of the global failure probability.

Finally, the global reliability index is calculated through the well known inverse relationship between reliability index and failure probability.

$\beta^{G}=-\Phi^{-1}\left(P_{f}{ }^{G}\right)$

\section{Application to an oil offshore platform in the bay of Campeche, Mexico}

Typical offshore platforms in Mexico

Data from typical marine platforms prone to have potential P- $\Delta$ problems, all octapods $(n=8)$, in Mexico have been provided (Campos et al., 2007; García-Tenorio et al., 2006). See Figure 5 for the elevation views of one of them. Table 1 shows geometrical data for these platforms. With these data, the axial buckling load of the platform deck legs is calculated.

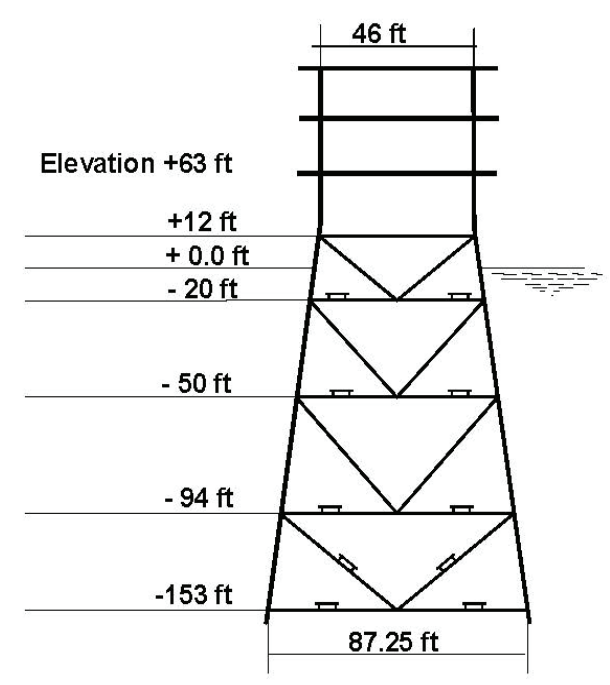

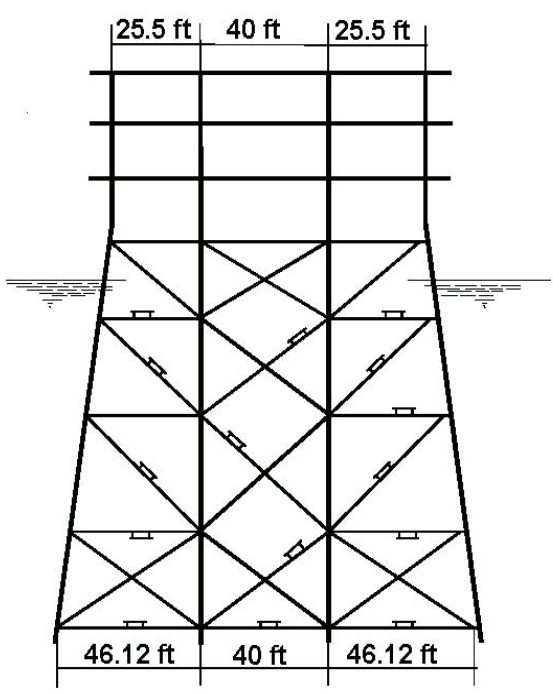

Figure 5. Elevations of vertical frames for a typical tall deck platform 


\begin{tabular}{cccccccc}
\hline Water & Lower deck & & & & & \\
\hline Depth $(\mathrm{m})$ & Elev. $(\mathrm{m})$ & $\mathrm{D}(\mathrm{cm})$ & $\mathrm{t}(\mathrm{cm})$ & $\mathrm{D} / \mathrm{t}$ & $\mathrm{H}_{\mathrm{d}}(\mathrm{cm})$ & $\mathrm{r}(\mathrm{cm})$ & $\mathrm{H}_{\mathrm{d}} / \mathrm{r}$ \\
\hline 63.40 & 15.850 & 121.92 & 3.175 & 38.40 & 1219.24 & 42.00 & 29.03 \\
50.00 & 19.100 & 129.54 & 4.45 & 29.14 & 1544.24 & 44.26 & 34.89 \\
57.40 & 19.100 & 121.92 & 5.29 & 23.04 & 1544.24 & 41.28 & 37.41 \\
60.75 & 19.100 & 129.54 & 5.29 & 24.48 & 1544.24 & 43.97 & 35.12 \\
84.25 & 19.100 & 129.54 & 5.29 & 24.48 & 1544.24 & 43.97 & 35.12 \\
\hline
\end{tabular}

Table 1. Geometrical properties of 5 typical tall deck offshore platforms in Mexico

\section{Axial buckling load on the deck legs}

Global and local buckling capacities are obtained for a typical platform in Mexico by assessing equations (2) and (3) for typical slenderness and D/t ratios and for steel A-36 which is commonly used in actual offshore platforms in Mexico. Figure 5 shows a comparison between the buckling capacities for a range of typical slenderness and $\mathrm{D} / \mathrm{t}$ ratios.

From Figure 6 it may be observed that, for all the typical slenderness and $\mathrm{D} / \mathrm{t}$ ratios shown, the global buckling mode governs the axial capacity.

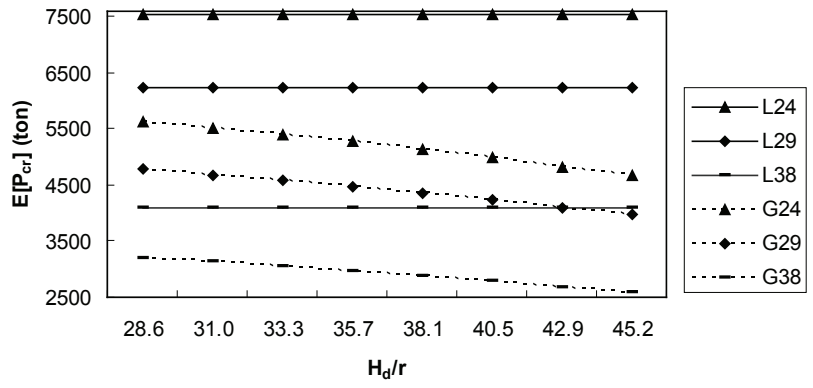

Figure 6. Comparison between critical local (L) and global (G) buckling loads for typical $\mathrm{D} / \mathrm{t}$ and slenderness ratios

\section{Calculation of the platform reliability with and without P- $\Delta$ effects}

The input data are the platform geometry and wave loading parameters as well as their statistics, which have been previously reported for the Bay of Campeche, Mexico (Bea, 1997). The software produces component reliability indices as an outcome.

On the other hand, the deck reliability indices without and with P- $\Delta$ effects are calculated by assuming that the mean vertical load is 7000 ton and the $C V_{Q}=0.4$. Table 2 shows the results where it is observed that the deck reliability index reduces significantly from 3.85 to 2.88. From Table 3 it is observed that the deck reliability index for the shear mode is 3.79. Given that the deck reliability for P- $\Delta$ effects mode is lower than the deck reliability for shear, the index for the mode with P- $\Delta$ effects is used instead of the one for shear.
Table 2. Calculation of $\beta_{\text {deck }}$ for the bending failure of the deck legs without $_{(1)}$ and with ${ }_{(2)} \mathrm{P}-\Delta$ effects

\begin{tabular}{cccccc}
\hline$\mu_{\mathrm{R} 1}=\mathrm{E}\left[\mathrm{M}_{\mathrm{p}}\right]_{1}$ & $\mu_{\mathrm{R} 2}=\mathrm{E}\left[\mathrm{M}_{\mathrm{p}}\right]_{2}$ & $\zeta_{\mathrm{R} 1}$ & $\zeta_{\mathrm{R} 2}$ & $\lambda_{\mathrm{R} 1}$ & $\lambda_{\mathrm{R} 2}$ \\
1394.86 & 1394.86 & 0.10 & 0.10 & 7.24 & 7.24 \\
$\mu_{\mathrm{L} 1}=\mathrm{E}\left[\mathrm{M}_{\mathrm{f}}\right]_{1}$ & $\mu_{\mathrm{L} 2}=\mathrm{E}\left[\mathrm{M}_{\mathrm{f}}\right]_{2}$ & $\zeta_{\mathrm{L} 1}$ & $\zeta_{\mathrm{L} 2}$ & $\lambda_{\mathrm{L} 1}$ & $\lambda_{\mathrm{L} 2}$ \\
322.64 & 444.88 & 0.39 & 0.41 & 5.70 & 6.01 \\
& & & & & \\
$\mathrm{CV}_{\mathrm{Mp}}$ & $\mathrm{CV}_{\mathrm{Q}}$ & $\mathrm{E}[\mathrm{Q}]$ & $\mathrm{CV}_{\mathrm{Mf}}$ & $\mathrm{CV}_{\mathrm{Mfa}}$ & \\
0.1 & 0.4 & 7000 & 0.4 & 0.430 & \\
& & $\beta_{(1)}$ & $\beta_{(2)}$ & & \\
& & 3.85 & 2.88 & & \\
\hline
\end{tabular}

Table 3. Calculation of the global reliability index for the shear failure mode of the platform in Mexico

\begin{tabular}{cc}
\hline Shear & \\
\hline 3.79 & $7.53 \mathrm{E}-05$ \\
6.18 & $3.22 \mathrm{E}-10$ \\
5.81 & $3.13 \mathrm{E}-09$ \\
7.27 & $1.81 \mathrm{E}-13$ \\
4.28 & $9.35 \mathrm{E}-06$ \\
3.74 & $9.2 \mathrm{E}-05$ \\
Lower bound & $9.2 \mathrm{E}-05$ \\
Upper bound & 0.000177 \\
Glob. $\mathrm{P}_{\mathrm{f}}=$ & 0.000128 \\
$\beta^{\mathrm{G}}=$ & 3.66 \\
\hline
\end{tabular}

The global reliability index is reduced from 3.67 to 2.88 as a result of the P- $\Delta$ effects as observed in Table 4.

Table 4. Calculation of the global reliability index for a platform in Mexico

\begin{tabular}{ccccc}
\hline & Without P- $\Delta$ & \multicolumn{3}{c}{ With P- $\Delta$} \\
& $\beta$ & $\mathrm{P}_{\mathrm{f}}$ & $\beta$ & $\mathrm{P}_{\mathrm{f}}$ \\
\hline Deck & 3.85 & $5.8 \mathrm{E}-05$ & 2.88 & 0.00196 \\
Bay 1 & 6.18 & $3.2 \mathrm{E}-10$ & 6.18 & $3.2 \mathrm{E}-10$ \\
Bay 2 & 5.81 & $3.1 \mathrm{E}-09$ & 5.81 & $3.1 \mathrm{E}-09$ \\
Bay 3 & 7.27 & $1.8 \mathrm{E}-13$ & 7.27 & $1.8 \mathrm{E}-13$ \\
Bay 4 & 4.28 & $9.4 \mathrm{E}-06$ & 4.28 & $9.4 \mathrm{E}-06$ \\
Foundation & 3.74 & $9.2 \mathrm{E}-05$ & 3.74 & $9.2 \mathrm{E}-05$ \\
& Lower bound & $9.2 \mathrm{E}-05$ & & 0.00196 \\
& $\mathrm{P}_{\mathrm{f}}$ & & & \\
& Upper bound & 0.00016 & & 0.00206 \\
& $\mathrm{P}_{\mathrm{f}}$ & & & \\
& Glob. $\mathrm{P}_{\mathrm{f}}$ & 0.00012 & & 0.00201 \\
& $\beta^{\mathrm{G}}=$ & $\mathbf{3 . 6 7}$ & & 2.88 \\
\hline
\end{tabular}


Finally, the global reliability index is calculated for several $C V_{Q}$ in order to assess the sensitivity of this index against the uncertainty on the vertical load. The results are shown in Figure 7.

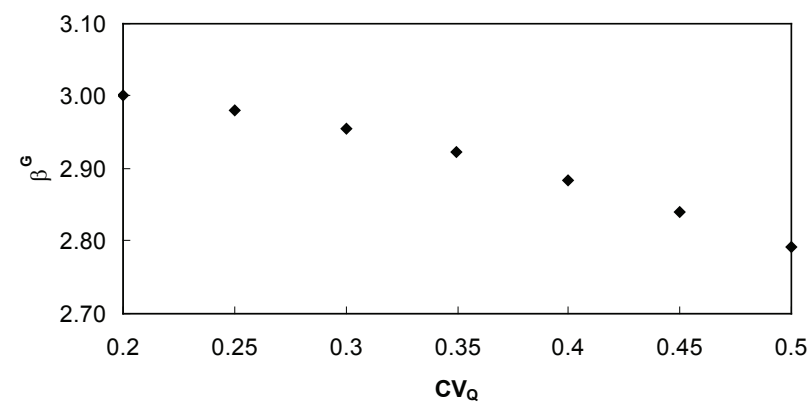

Figure 7. Global platform reliability index as a function of the vertical load uncertainty

\section{Discussion of results}

It is observed that, for the example illustrated, the P- $\Delta$ effect produces a significant difference on the global reliability index. Given that the acceptable reliability index, for a platform with high consequences of failure like the one studied here, is 3.6 (PEMEX, 2000) the P- $\Delta$ effects make the platform do not pass the reliability requirement. If these effects would not be taken into account, one might believe that the platform reliability is satisfactory. Therefore, a platform with slender deck legs and heavy vertical loads, should be analyzed or revised including the $\mathrm{P}-\Delta$ effects.

From Figure 7, it is observed that even with a low uncertainty on the vertical load, the platform reliability index is well below the acceptable value.

From Figure 5, the global buckling mode was found to be the one that governs the axial capacity of deck legs for the ranges of slenderness ratios and other geometrical characteristics that are typical in offshore platforms in Mexico. Also, the wave-on-deck loading condition contributes to make of the deck the critical component on the platform where decks have slender legs and significant vertical load.

\section{Conclusions and recommendations}

The deck failure mode may become the dominant mode in the platform failure, if the platform deck has slender legs and heavy vertical load. In these cases, the P- $\Delta$ effect should be considered for local design and damage assessment of platforms decks. Additional bracings and elements on the deck legs may contribute to reduce the slenderness ratio and, therefore, mitigate the reliability reduction due to $\mathrm{P}-\Delta$ effects.
The practice of increasing the vertical load before analysis should be carefully examined because of its negative effect on the platform safety level, particularly in the case of decks with important P- $\Delta$ effects.

It is suggested to perform cost/benefit studies to appraise the limitations of using very tall decks, for platforms with the type of problems shown here, and to update the design and assessment code.

Also, the effect of a non-uniform distribution of vertical load on the deck area is an aspect that requires further study.

\section{Acknowledgements}

The authors thank PEMEX and IMP from México for the platforms information that served as a basis for this article.

\section{References}

American Petroleum Institute (API). Recommended Practice for Planning, Designing and Constructing Fixed Offshore PlatformsLoad and Resistance Factor Design, 1st ed., Washington D.C., API RP 2a-LRFD, July 1993.

Ang-Alfredo H.S., Tang-Wilson H. Pobability Concepts in Engineering Planning and Design, volume I, 2nd ed., New York, John Wiley and Sons, 2007.

Ang-Alfredo H.S., Tang-Wilson H. Probability Concepts in Engineering Planning and Design, on: volume II, Decision, Risk and Reliability, New York, John Wiley and Sons, 1984.

Bea R.G. Risk Based Oceanographic Criteria for Design and Requalification of Platforms in the Bay of Campeche. Report to Petroleos Mexicanos and Instituto Mexicano del Petroleo, University of California at Berkeley, 1997.

Bruneau M., Uang Ch.M., Whittaker A. Ductile Design of Steel Structures, New York, McGraw-Hill, 1998.

Campos D., Soriano A., Ortega C., Alamilla J., León-Sepulveda F., Morales-Contreras J.L., García-Tenorio M., Rendón-Conde C., López-Cornejo M. Investigaciones recientes con fines de actualizar la Norma de Referencia sobre el diseño y evaluación de plataformas marinas fijas en el Golfo de México, on: 9th. Nacional Symposium of the Mexican Society of Earthquake Engineering, Ixtapan de la Sal, Estado de Mexico, 2007.

Chen W.F. (editor). Handbook of Structural Engineering, published by CRC Press, Inc., 1997.

Cornell A. Structural Safety Specification Based on Second-Moment Reliability, Symposium IABSE, London, 1969.

Cox J.W. Tubular Member Strength Equations for LRFD. Final report API PRAC Project 86-55, 1987.

De León D. Probabilidad de falla de marcos de acero esbeltos sujetos a excitación sísmica, on: Proceedings of the XII National Congress on Earthquake Engineering, Morelia, Mexico, 1999. 
De León, D. P- $\Delta$ Effects on the Reliability of Offshore Platforms, on: Proceedings of the I International PEP-IMP Symposium on Risk and Reliability Assessment for offshore Structures, Mexico, DF, 2001

De León D., Ang-Alfredo H.S. Reliability-Based Design of a Marine Platform in Mexico, on: Proceedings of the 9th ICASP (International Conference on Applications of Statistics and Probability in Civil Engineering), San Francisco, USA., 2003.

De León D., Campos D. Recent Developments on the Design of Steel Marine Platforms, on: VI International Symposium on Steel Structures organized by the IMCA and the SMIE, Puebla, Mexico, 1999.

Ditlevsen O. Narrow Reliability Bounds for Structural Systems. Journal of Structural Mechanics, ASCE, volume 1 (issue 4), 1979: 453-472.

Galambos T.V., Lin F.J., Johnston B.G. Basic Steel Design with LRFD, Prentice Hall, 1996.

García-Tenorio M., López-Cornejo M., Morales-Contreras J.L., Rendón-Conde C., Campos D., Ortega C. y Soriano A. Efecto de la elevación de cubierta inferior en la resistencia lateral última y probabilidad de falla por oleaje de plataformas marinas fijas tipo jacket, on: Proceedings of the XV Nacional Congress on Structural Engineering. Puerto Vallarta, Mexico, 2006.

Gupta A., Krawinkler H. Dynamic P-Delta Effects for Flexible Inelastic Steel Structures. Journal of Structural Engineering, volume 126 (issue 1), January 2000: 145-154.

IMP (Instituto Mexicano del Petróleo) Criterio transitorio para el diseño y evaluación de plataformas marinas en la Bahía de Campeche, 1st ed., Mexico, DF, 1997.
Mortazavi M., Bea R.G. A Probabilistic Screening Methodology for Steel, Template Type Offshore Platforms. Report to Joint Industry Project Sponsors, Marine Technology and Management Group, Department of Civil and Environmental Engineering, University of California at Berkeley, California, 1996.

PEMEX. Norma de referencia NRF-003-PEMEX-2000 para diseño y evaluación de plataformas marinas en la Bahía de Campeche. Mexico, DF, 2000.

Salmon C.G., Johnson J.E. Steel Structures-Design and Behavior Emphasizing Load and Resistance Factor Design, 4th ed., Ed. Harper Collins, 1996.

Stear D.J., Zhaohui J., Bea R.G. TOPCAT: Template Offshore Platform Capacity Assessment Tools. Marine Technology and Management Group. Department of Civil and Environmental Engineering. University of California, Berkeley, 1997.

SPC. Statistical Analysis of Tensile data for Wide Flange Structural Shapes. Structural Shape Producers Council, 1994.

\section{Citation of this article:}

\section{Chicago citation}

De León-Escobedo, David, Dante Campos. P- $\Delta$ Effects on the Reliability of Oil Offshore Jacket Platforms in Mexico. Ingeniería Investigación y Tecnología XIII, 03 (2012): 263-270.

\section{ISO 690 citation}

De León-Escobedo, D.; Campos D. P- $\Delta$ Effects on the Reliability of Oil Offshore Jacket Platforms in Mexico. Ingeniería Investigación y Tecnología, volumen XIII (número 3), julio-septiembre 2012: 263-270.

\footnotetext{
About the authors

David De León-Escobedo. Professional Engineer on California (civil engineering) since 1996. Ph. D. (1991-1996) in Engineering from the University of California, Irvine. He worked as project engineer LATISA, México, DF. Detail Engineering for SICARTSA plant in Lázaro Cárdenas, Mich., from 1983 to 1984, project engineer in the company W. Koo and Associates. Bridge design and assessment for CALTRANS, Orange, California, from 1996 to 1997 and project engineer at IMP (Mexican Petroleum Institute): Risk and reliability assessment for marine offshore platforms, vibration assessment of platforms, safety and code assessment for oil pipelines, mediation for construction controversy between SCT about the Chiapas-Malpaso bridge, from 1999 to 2005. He is Professor at UAEM, Engineering School, since 2005.

Dante Campos. Civil Engineer from the National University of Engineering (UNI), Peru (1978-1983). Doctor in Engineering (2005) from National University of Mexico (UNAM). He studied Master in Egineering (structures), UNAM (1992-1993) and Master in Sciences (Systems Engineering), UNI, Peru (1987-1989). He is researcher and expert in risk and structural reliability of the Mexican Petroleum Institute since 1998, with applications to marine platforms, onshore and offshore pipelines, assessment and vibration analysis of structures, extension of lifetime, seismic engineering and codes. Prize IMP, 1st place, the years 2004 and 2007 in Industrial Application and the year 2011 in Innovation. He is Professor in the Postgraduate of Structures of the National Polytechnic Institute, since 2007, and of the UAEMex, from 1993 to 2002. Project engineer since 1983, with emphasis to the structural design of buildings and bridges, in LABCI, Jack Lopez Engineers, MINERO PERU, in Peru.
} 